\title{
A cytological and histological study of acute premyelocytic leukaemia
}

\author{
JEAN BERNARD, J. LASNERET, J. CHOME, J. P. LEVY, AND M. BOIRON \\ From the Laboratory of Experimental Haematology, Research Institute for \\ Blood Diseases, Hospital of Saint Louis, Paris
}

SYNOPSIS Among the acute leukaemias of the granulocytic group, acute premyelocytic leukaemia is distinguished by the severity of its haemorrhages, the frequency of hypofibrinaemia, a rapidly fatal course, and an unusual cellular hyperplasia. Myelograms show an increased proportion (average $80 \%$ ) of characteristic cells of large diameter, with numerous azurophil granules. The infiltration of other organs is inconstant.

\section{MATERIAL AND METHODS}

Acute premyelocytic leukaemia represents about $6.8 \%$ of all cases of acute leukaemia seen at our Institute (Bernard, Boiron, Weil, Levy, Seligmann, and Najean 1962). Between 1956 and August 1962, 34 cases of acute premyelocytic leukaemia from a total of 497 cases of acute leukaemia were seen. We have chosen for this study 25 cases followed up until death with, in 12 cases, a full necropsy.

The diagnostic criterion used was the presence of a very large proportion of cells of the premyelocyte type (over $50 \%$ and often 80 to $100 \%$ ) in the bone marrow, associated with the clinical and haematological features of acute leukaemia.

Cytological studies were made on bone marrow and blood smears stained by the May-Grünwald-Giemsa method. The histological features of the bone marrow and various viscera obtained at necropsy were examined in tissues fixed in Bouin's fluid and stained with haematooxylin-phloxin-saffron.

\section{HAEMATOLOGICAL STUDY}

The clinical characteristics of acute premyelocytic leukaemia were first described in a previous communication (Bernard, Mathé, Boulay, Céoara, and Chomé, 1959). Table I presents the principal haematological data on the present series of cases. Anaemia was generally intense with a red cell count at first examination of under $2 \frac{1}{2}$ million per c.mm. in 18 cases. The leucocyte count was variable, but often diminished (less than 5,000 c.mm. in 17 cases). Premyelocytes were found in the blood in 21 of the cases, but their number showed considerable individual variations. The myelogram as a rule

\footnotetext{
Received for publication 21 November 1962.
}

showed a massive increase in the premyelocytes, which made up an average of $80 \%$ of the medullary elements; in three cases, however, their concentration was between $50 \%$ and $70 \%$ (cases $2,8,19$ ).

Thrombocytopenia was found in 23 out of 24 cases and was usually considerable (less than 50,000 platelets per c.mm. in 18 of the cases). Rapid fibrinolysis was seen in 10 out of 20 cases in which it was studied; considerable hypofibrinaemia was seen in 10 cases out of 11 .

The course was as a rule acute, and remissions were exceptional. In 21 of the 24 cases in which the survival time could be evaluated, it was shorter than a month. Death was generally associated with haemorrhagic manifestations.

\section{CYTOLOGICAL STUDY}

The malignant premyelocyte is a cell of considerable size (15 to $20 \mu)$, characterized even when only slightly magnified by a great number of granulations, which sometimes give it the appearance of a muriform cell. When examined at a high magnification, it is clearly distinct from the myeloblast. The nucleus is large and often eccentric. Its chromatin is less dense than that of the normal premyelocyte, and distinguished from that of the myeloblast by its coarser texture and greater density. Some of these cells are nucleolated but the majority are not. It is difficult, however, to make an exact study of all the nuclei, because some are almost completely covered by the cytoplasmic granulations. The cytoplasm is abundant and basophile or, less frequently, lilac coloured. The azurophil granules cover almost the entire surface of the cell; some specific granulations 
TABLE I

\begin{tabular}{|c|c|c|c|c|c|c|c|c|c|c|}
\hline \multirow{3}{*}{ Case } & \multirow{3}{*}{ Age } & \multirow{3}{*}{ Sex } & \multirow{2}{*}{\multicolumn{3}{|c|}{ Haemogram }} & \multicolumn{4}{|c|}{ HAEMATOLOGICAL DATA IN PRESENT S } & \multirow{3}{*}{$\begin{array}{l}\text { SERIES } \\
\text { Remission }\end{array}$} \\
\hline & & & & & & \multirow{2}{*}{$\begin{array}{l}\% \text { of } \\
\text { Premyelo- } \\
\text { cytes on } \\
\text { Myelo- } \\
\text { gram }\end{array}$} & \multicolumn{3}{|c|}{ Haemostasis } & \\
\hline & & & $\begin{array}{l}\text { White Cell } \\
\text { Count } \\
\text { (per } \\
\text { c.mm.) }\end{array}$ & $\begin{array}{l}\text { Red Cell } \\
\text { Count } \\
\text { (per } \\
\text { c. } m m .)\end{array}$ & $\begin{array}{l}\% \text { Pre- } \\
\text { myelocytes }\end{array}$ & & $\begin{array}{l}\text { Platelets } \\
\text { (per } \\
\text { c.mm.) }\end{array}$ & $\begin{array}{l}\text { Fibrino- } \\
\text { lysis }\end{array}$ & $\begin{array}{l}\text { Hypofi- } \\
\text { brinaemia }\end{array}$ & \\
\hline 1 & 38 & $\mathbf{F}$ & 18,000 & 1.9 & 42 & 71 & 50,000 & + & 1 & $\mathbf{0}$ \\
\hline 2 & 8 & $\mathbf{F}$ & 6,400 & $1 \cdot 3$ & 44 & 60 & 35,000 & + & 1 & $\mathbf{0}$ \\
\hline 3 & $5 \frac{1}{2}$ & $\mathbf{F}$ & 4,600 & $2 \cdot 3$ & 40 & 100 & 35,000 & + & 1 & $\mathbf{0}$ \\
\hline 4 & 10 & $\mathbf{F}$ & 2,000 & 1.4 & 22 & 80 & 40,000 & 0 & \pm & $\mathbf{0}$ \\
\hline 5 & 7 & $\mathbf{F}$ & 234,000 & 1.6 & 98 & 93 & 45,000 & + & 1 & 0 \\
\hline 6 & 32 & $\mathbf{F}$ & 8,200 & 1.4 & 76 & 100 & 25,000 & $i$ & 1 & 0 \\
\hline 7 & 16 & $\mathbf{M}$ & 3,400 & 1.9 & 62 & 70 & 35,000 & + & + & Incomplete \\
\hline 8 & 53 & $\mathbf{F}$ & 17,600 & $3 \cdot 2$ & 18 & 50 & 100,000 & 1 & 1 & 0 \\
\hline 9 & 9 & $\mathbf{M}$ & 3,200 & 2.4 & 42 & 73 & 25,000 & 1 & 1 & $\mathbf{0}$ \\
\hline 10 & 65 & $\mathbf{F}$ & - & - & - & 94 & - & $i$ & i & $\mathbf{0}$ \\
\hline 11 & 12 & $\mathbf{F}$ & 1,000 & $2 \cdot 0$ & 2 & 100 & 30,000 & 0 & + & $\mathbf{0}$ \\
\hline 12 & 29 & $\mathbf{M}$ & 3,400 & 1.5 & 40 & 76 & 30,000 & 1 & 1 & 0 \\
\hline 13 & 36 & $\mathbf{F}$ & 200 & 1.0 & 32 & 100 & 40,000 & 0 & + & 0 \\
\hline 14 & 52 & $\mathbf{M}$ & 800 & $1 \cdot 3$ & 4 & 100 & 45,000 & $\mathbf{0}$ & + & $\mathbf{0}$ \\
\hline 15 & 16 & $\mathbf{F}$ & 9,600 & $2 \cdot 4$ & 35 & 72 & 30,000 & 0 & + & $\begin{array}{l}\text { Complete } \\
\text { for } 1 \mathrm{mth} \text {. }\end{array}$ \\
\hline 16 & 7 & $\mathbf{M}$ & 1,000 & 3.4 & $\mathbf{0}$ & 70 & 250,000 & $\mathbf{0}$ & 1 & $\begin{array}{l}\text { Complete } \\
\text { for } 4 \mathrm{mth} \text {. }\end{array}$ \\
\hline 17 & 6 & $\mathbf{F}$ & 1,400 & $2 \cdot 8$ & 8 & 93 & 15,000 & + & & Complete \\
\hline 18 & 18 & $\mathbf{M}$ & 5,000 & $1 \cdot 1$ & 52 & 100 & 40,000 & $\mathbf{0}$ & 1 & $\begin{array}{l}\text { Ior } 12 \mathrm{mtn} \text {. } \\
\text { Incomplete }\end{array}$ \\
\hline 19 & 47 & $\mathbf{M}$ & 2,400 & 1.4 & 15 & 55 & 35,000 & + & & 0 \\
\hline 20 & 21 & $\mathbf{M}$ & 1,200 & 3.5 & 30 & 100 & 30,000 & 0 & + & $\mathbf{0}$ \\
\hline 21 & 13 & $\mathbf{M}$ & 600 & $3 \cdot 5$ & 0 & 96 & 160,000 & 0 & 1 & $\mathbf{0}$ \\
\hline 22 & 14 & $\mathbf{F}$ & 2,800 & 2.0 & 34 & 78 & 60,000 & + & + & 0 \\
\hline 23 & 5 & $\mathbf{M}$ & 3,800 & 2.8 & 37 & 70 & 100,000 & \pm & \pm & $\mathbf{0}$ \\
\hline 24 & 47 & $\mathbf{M}$ & 1,800 & $3 \cdot 1$ & 0 & 96 & 85,000 & 0 & $\bar{t}$ & 0 \\
\hline 25 & 45 & $\mathbf{M}$ & 8,600 & $2 \cdot 5$ & 77 & 90 & 45,000 & + & 0 & 0 \\
\hline
\end{tabular}

Duration Cause of Death
of Course
from First
Clinical
Examina-
tion in
Days

6 Haemorrhages, hypertherno

1 haematemesis, cerebral \&
0 haemorrhage of Cerebromeningeal haemorrhage 2 Cerebromeningeal haemor丶hage 11 Haemorrhages, hypertherniia Haemorrhages

Cerebromeningeal haemorritiage ? ? Gastrointestinal haemorrh羿e Cerebral haemorrhage Haemorrhages, hyperthernin Cerebromeningeal haemorthage Hyperthermia, neurologicabigns Hyperthermia, neurologica gign Infection Haemorrhages, hyperther舀a ? Cerebral haemorrhage Gastrointestinal haemorrhage Cachexia

Haemorrhages, hypertherruba Haematuria, hyperthermia Gastrointestinal haemorrhase Haematemesis

$I=$ no specimen

can be observed among them. Anomalous by their number alone, the cytoplasmic granulations are usually abnormal also by their size, which exceeds that of the granules in normal premyelocytes. A few cells may even contain enormous polyhedral azurophil granulations. In one case (no. 24) most of the cells contained accumulations of Auer bodies.

Other malignant elements seen include haemocytoblasts, myeloblasts, and particularly monocytoid haemoblasts, the last always in small numbers.

\section{HISTOLOGICAL STUDY}

Macroscopically haemorrhagic lesions, visceral or cerebromeningeal, were not seen more frequently than in other varieties of leukaemia, contrary to what might have been expected on the basis of the clinical observations. The principal results obtained by histological examination are presented in Table II.

BONE MARROW The features of the marrow sections are highly characteristic because of the massive and uniform infiltration with fairly large (15 to $20 \mu)$, and very unusual cells which have clearly delineated round or oval contours, with a rounded, eccentric nucleus and very dense chromatin. A few mitoses are noted. The cytoplasm, of a rusty colour reminiscent of haematoxylin-phloxin-saffron staining, is granular but contains no distinguishable inclusions or special staining affinity. By their diameter, chromatin, and cytoplasmic colour, these cells are distinct from the plasmocytes which at first sight they resemble but which lack these characteristic features. There is almost absolute uniformity, although undifferentiated leucoblastic elements are sometimes observed. Four cases showed sparse islets of erythroblasts (cases $1,13,14$, and 24). The leukaemic proliferation provokes no invasion of bone, and the cortical layers and spicules are normal. Only one of our cases (no. 15) did not fulfil this criterion because death took place during a complete remission.

FREQUENCY OF INVOLVEMENT OF OTHER ORGANS This frequency was estimated on the basis of 11 necropsies. Infiltration of organs other than the bone marrow was found to be inconstant. It was impossible to calculate the frequency exactly, because not all the necropsies were complete, although the spleen and liver (11 cases), kidneys and lungs ( 9 cases), and 
TABLE II

Histology OF PREMYelocytic LeUKAEMIA IN 11 CASES

\begin{tabular}{|c|c|c|c|c|c|c|c|c|c|c|c|c|c|c|}
\hline $\begin{array}{l}\text { Case } \\
\text { No. }\end{array}$ & $\begin{array}{l}\text { Bone } \\
\text { Marrow }\end{array}$ & Spleen & $\begin{array}{l}\text { Lymph } \\
\text { Node }\end{array}$ & Liver & Kidney & $\begin{array}{l}\text { Perirenal } \\
\text { Tissue }\end{array}$ & $\begin{array}{l}\text { Ad- } \\
\text { renals }\end{array}$ & Lungs & Brain & $\begin{array}{l}\text { Peri- } \\
\text { pheral } \\
\text { Nerve }\end{array}$ & $\begin{array}{l}\text { Ovary } \\
\text { or } \\
\text { Testicle }\end{array}$ & $\begin{array}{l}\text { Uterus and } \\
\text { Tubes }\end{array}$ & Heart & $\begin{array}{l}\text { Intes- } \\
\text { tine }\end{array}$ \\
\hline $\begin{array}{r}1 \\
2867\end{array}$ & $\begin{array}{l}+ \\
\text { Massive } \\
\text { premyelo- } \\
\text { cytes }\end{array}$ & $\begin{array}{l}+ \\
\text { Red pulp } \\
\text { poly- } \\
\text { morphs }\end{array}$ & $\begin{array}{l}+ \\
\text { Sinus } \\
\text { poly- } \\
\text { morphs }\end{array}$ & $\begin{array}{l}+ \\
\text { Periportal } \\
\text { sinusoides } \\
\text { capillaries } \\
\text { polymorphs }\end{array}$ & $\begin{array}{l}0 \\
\text { is }\end{array}$ & $\begin{array}{l}+ \\
\text { Premyelo- } \\
\text { cytes }\end{array}$ & 1 & 1 & 1 & 1 & I & 1 & 1 & 1 \\
\hline $\begin{array}{r}2 \\
3403\end{array}$ & $\begin{array}{l}+ \\
\text { Massive } \\
\text { premyelo- } \\
\text { cytes }\end{array}$ & 0 & 0 & $\begin{array}{l}+ \\
\text { Periportal } \\
\text { polymorphs }\end{array}$ & $\begin{array}{r}0 \\
\mathbf{1 5}\end{array}$ & $\begin{array}{l}+ \\
\text { Massive } \\
\text { haemorr- } \\
\text { hage foci } \\
\text { polym. }\end{array}$ & 1 & $\begin{array}{l}+ \\
\text { Vessels, } \\
\text { alveolar } \\
\text { walls } \\
\text { polym. }\end{array}$ & 1 & 1 & I & 1 & 1 & I \\
\hline
\end{tabular}

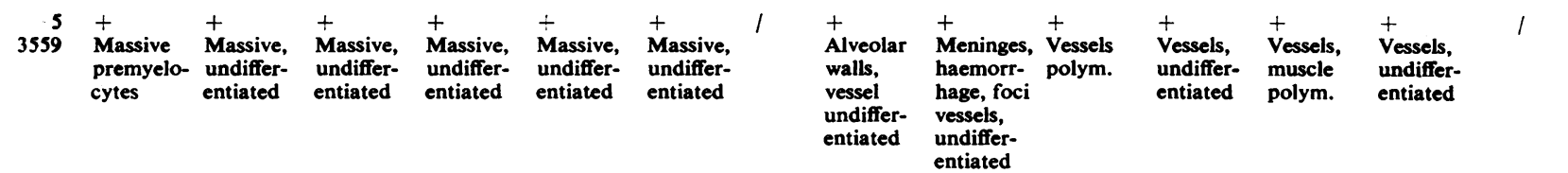

\begin{tabular}{|c|c|c|c|}
\hline $\begin{array}{r}6 \\
4268\end{array}$ & $\stackrel{+}{\text { Massive }}$ & $\begin{array}{l}+ \\
\text { Red pulp } \\
\text { undiffer- } \\
\text { entiated }\end{array}$ & 1 \\
\hline $\begin{array}{r}10 \\
8418\end{array}$ & $\begin{array}{l}+ \\
\text { Massive } \\
\text { premyelo- } \\
\text { cytes }\end{array}$ & 0 & 0 \\
\hline $\begin{array}{c}11 \\
12713\end{array}$ & $\begin{array}{l}+ \\
\text { Massive } \\
\text { premyelo- } \\
\text { cytes }\end{array}$ & $\begin{array}{l}+ \\
\text { Red pulp } \\
\text { polym. }\end{array}$ & 1 \\
\hline
\end{tabular}
Periportal,
entiated

$\mathbf{0}$

1

$\stackrel{+}{\text { Massive }} \stackrel{+}{\text { Red pulp }}$

premyelo- polym.

cytes

\section{$\stackrel{+}{\text { Periportal }}$ \\ premyelo- \\ cytes}

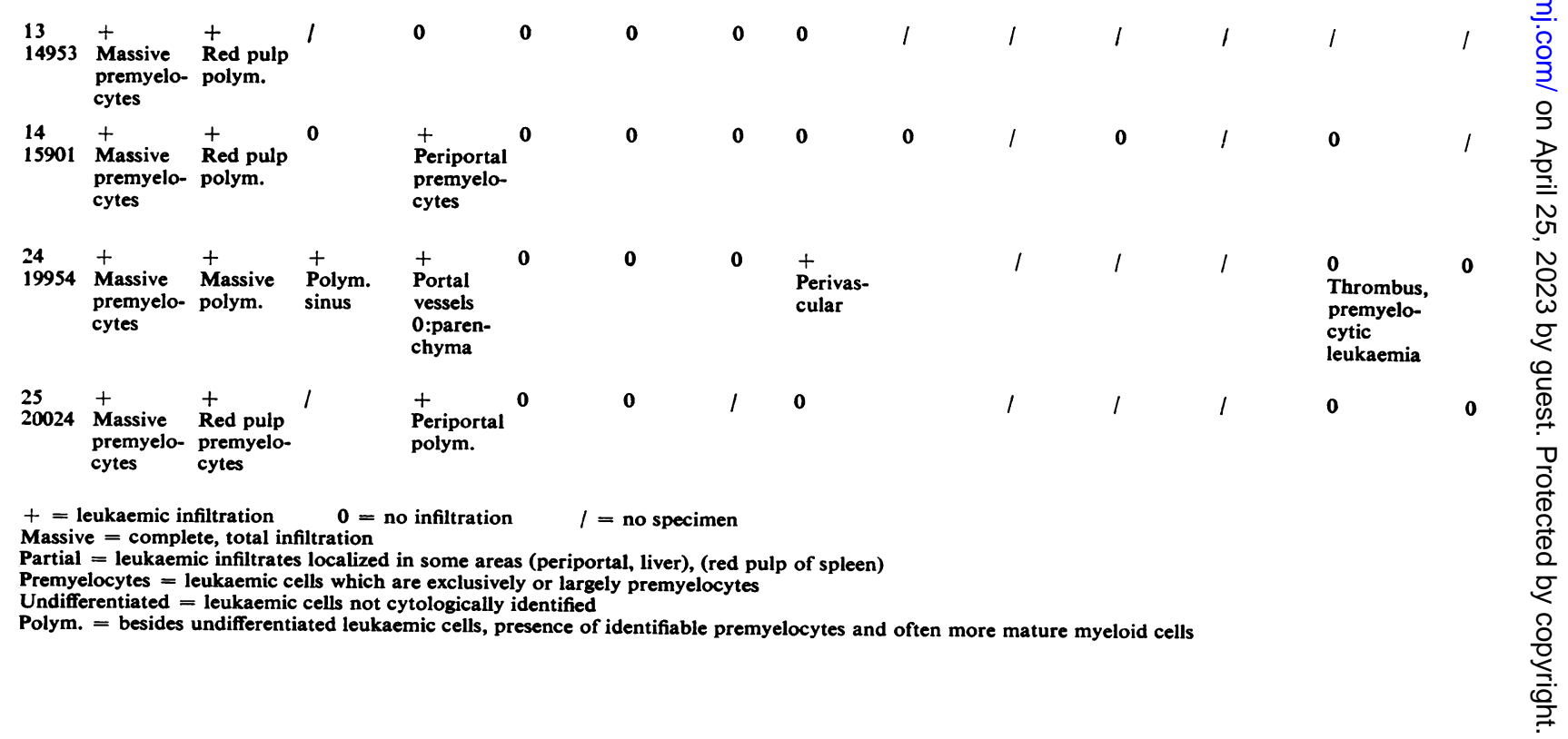




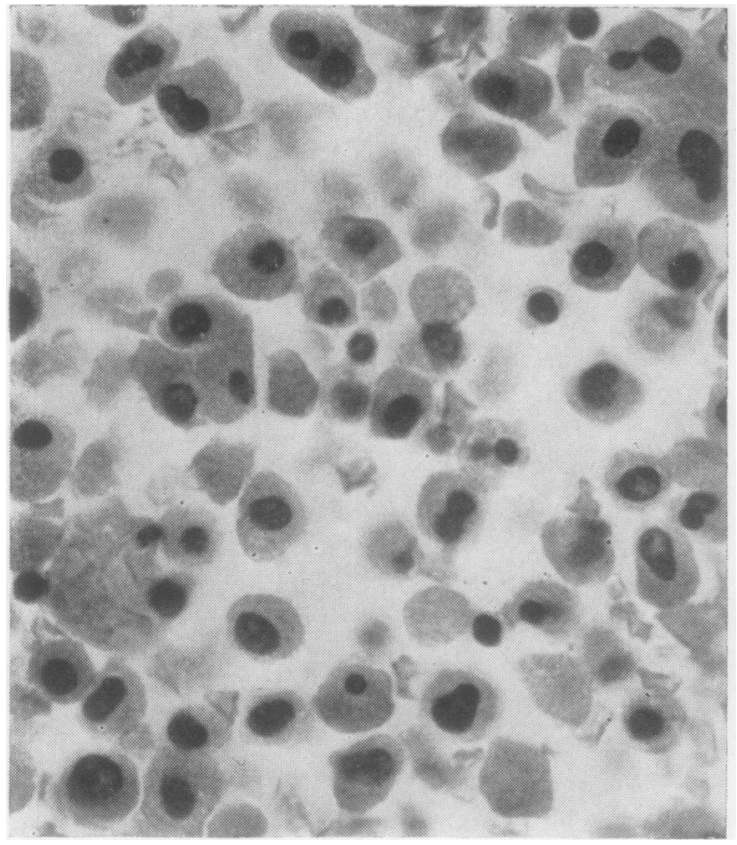

FIG. 1

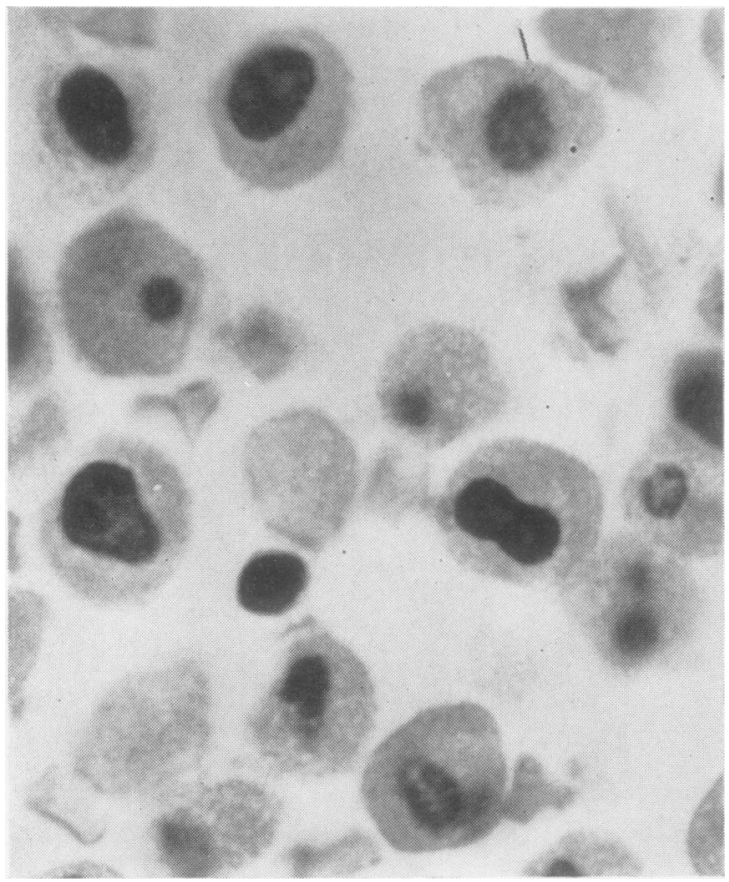

FIG. 2

FIG. 1. Premyelocytic infiltration of the bone marrow. Haematoxylin-phloxin-saffron $\times 820$.

FIG. 2. Premyelocytes as they appear under high-power magnification in bone marrow sections. Haematoxylinphloxin-saffron $\times 1,500$.

FIG. 3. Premyelocytic infiltration of the white pulp of the spleen. Haematoxylin-phloxine-saffron $\times 225$.

FIG. 4. Premyelocytic infiltrate in the perirenal fat tissue. Haematoxylin-phloxine-saffron $\times 150$.

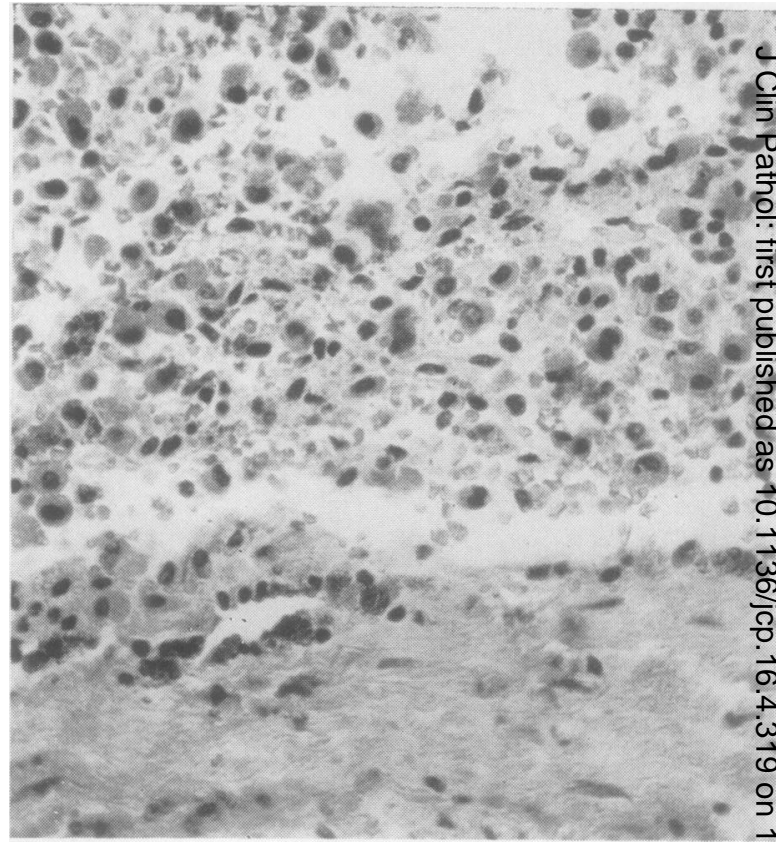

FIG. 3

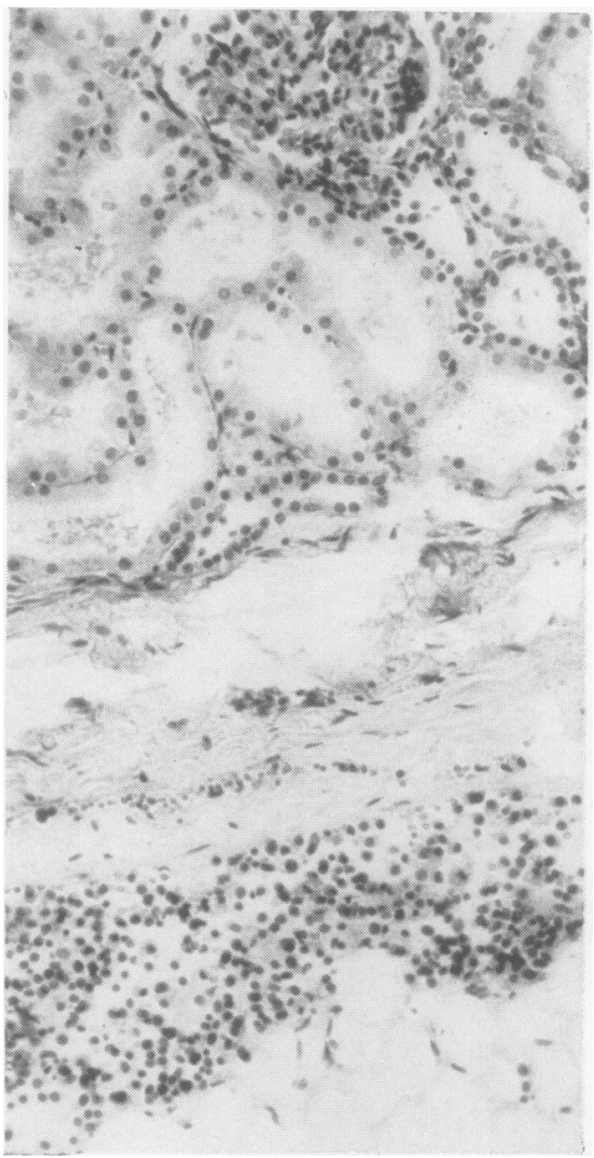

FIG. 4 


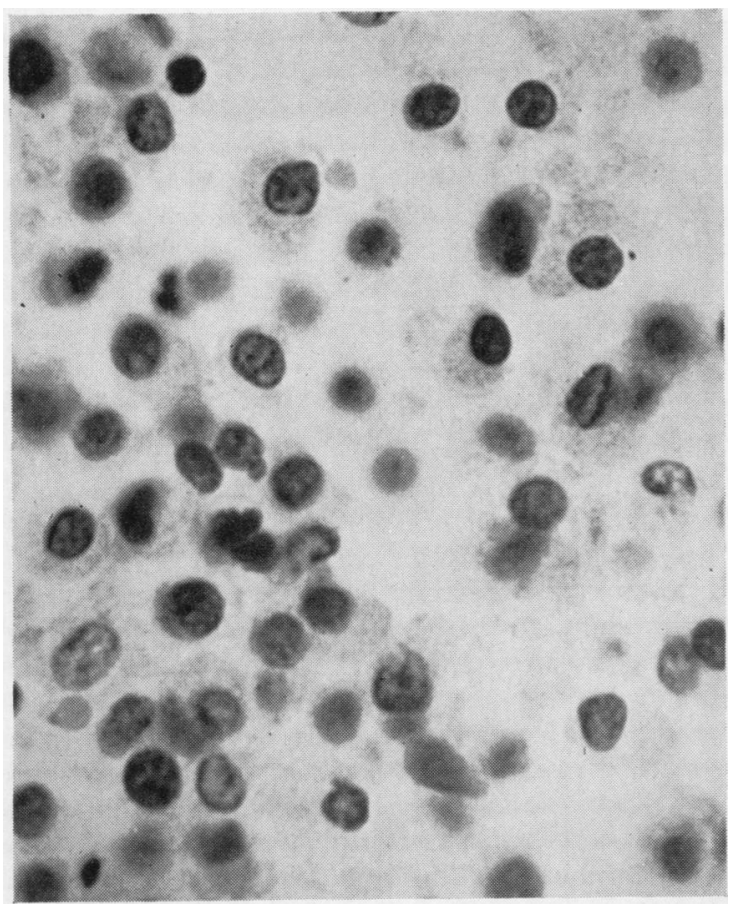

FIG. 5

FIG. 5. Premyelocytic infiltrate in the perirenal fat tissue (same as Fig. 4). Haematoxylin-phloxine-saffron $\times 820$.

FIG. 6. Leukaemic premyelocytes (bone marrow smear). May-Grünwald-Giemsa $\times 820$.

FIG. 7. Leukaemic premyelocytes (bone marrow smear). May-Grünwald-Giemsa $\times 1,500$.

lymph nodes ( 7 cases) were examined sufficiently systematically to warrant conclusions. The organs most frequently affected were the spleen $(9$ cases out of 11) and the liver ( 8 cases out of 11). The lungs (3 out of 9), lymph nodes ( 3 out of 7 ), kidneys ( 1 out of 9), and perirenal zone ( 3 out of 9) were less frequently affected. A leukaemic meningeal focus was found in two cases; leukaemic infiltrations in a cerebral haemorrhagic focus in the uterine muscle (case 5), in the heart, around a peripheral nerve, and in perihypophyseal vessels were also found. In one case (no. 2) there was a massive infiltration of the striated muscles near a haemorrhagic focus.

TYPE OF INFILTRATION Unlike those of the bone marrow, the leukaemic infiltrates of the viscera are not uniform. Only in three specimens (case 1, perirenal zone; case 2, liver and spleen) were premyelocytes found almost exclusively. In all other cases the visceral infiltrates were pleomorphic; premyelocytes were identifiable, often in large

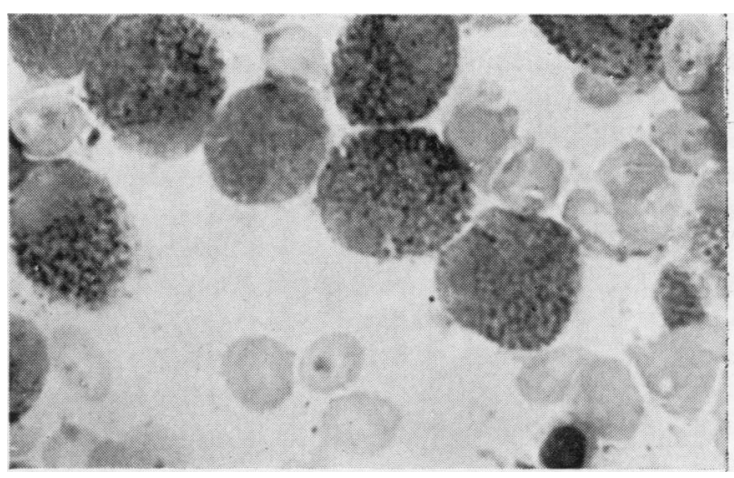

FIG. 6

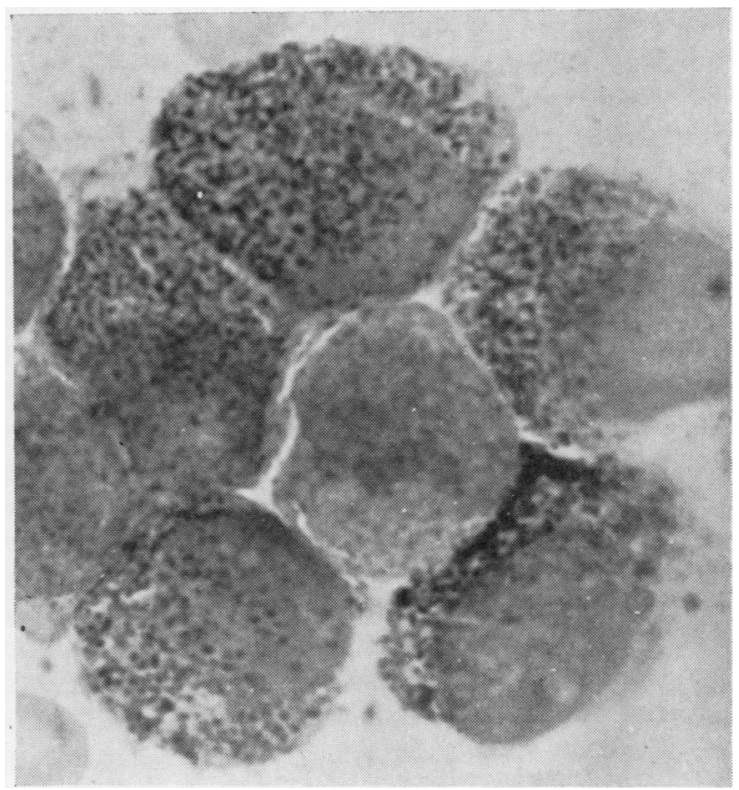

FIG. 7

numbers, but always in the company of other cells which could not be cytologically classified, as is the rule in histological sections. These cells could only be recognized as undifferentiated haemoblasts. Their features were variable; they showed an irregular, large nucleus, less dense than that of the premyelocytes, with relatively less abundant cytoplasm. Occasionally, more mature myeloid cells were also seen (metamyelocytes, granulocytes). In some cases no premyelocytes could be identified in the visceral infiltrates; the features in these cases were completely undifferentiated.

TOPOGRAPHY OF INFILTRATION In one case (no. 5), there was massive visceral infiltration of the principal organs (liver, spleen, kidneys, perirenal zone, 
lymph nodes, lungs, uterus) but in all other cases visceral infiltration was incomplete.

Spleen The splenic structure remained recognizable but the white pulp was hypoplastic; the infiltration was in the red pulp. In only one case was total infiltration seen (no. 25).

Liver Infiltrates were periportal and often very small; the leukaemic cells sometimes infiltrated the sinusoid capillaries.

Perirenal tissue In three cases infiltration was found, sometimes near a haemorrhagic focus.

Lungs Infiltration was localized in the alveolar walls; the vessels were stuffed with leukaemic cells.

Lymph nodes In the various lymph nodes obtained after death infiltration was either massive, with capsular and pericapsular invasion, or limited, more or less effacing the lymph node structure but not going beyond the capsule.

Other viscera The cerebrum and cerebellum may be infiltrated. The leucocytic cells infiltrated the haemorrhagic foci and the meninges and filled the vessels. In the uterus, infiltration was localized among the muscle fibres. The vessels of the ovaries were stuffed with leucocytic elements.

NON-SPECIFIC LESIONS Non-specific lesions were frequently found. In the spleen, haemorrhagic foci, congestion, and the stigmata of haemolysis are nearly always found. In the liver vascular congestion and signs of cholestasis were sometimes seen; hepatic steatosis existed in one case (no. 24). In one case (no. 11) there was hepatic and splenic mycosis. In the lungs there may be foci of congestion, infarction, or even necrosis. Pancreatic and adrenal necrosis and congestion are also possible.

\section{DISCUSSION}

Although the diagnosis of acute premyelocytic leukaemia generally offers no difficulty, a number of problems must be considered.

Cytologically, the leukaemic myeloblast shows a younger nucleus and fine chromatin structure, nucleolated or even with several nucleoli; the cytoplasm is abundant and basophilic, containing only a few azurophil granulations and sometimes even a few Auer bodies. A few premyelocytes are occasionally found in myeloblastic leukaemia (not more than 5 to $10 \%$ ). Histologically, the features differ considerably $\underline{\text { o }}$ from those of premyelocytic leukaemia. The cells have a larger nucleus, with less dense chromatin and $\stackrel{D}{\rightarrow}$ more irregular contours (notched); the cytoplasm is less abundant, with less distinct contours and variable staining characteristics; there is as a rule a tendency to basophilia but always the staining affinity differs from that of premyelocytes.

A much more difficult problem is posed by some acute leukaemias of the granulocyte group, which have the clinical features of acute premyelocytic $\vec{\omega}$ leukaemia. Their cytological features are polymorphous in the bone marrow and the blood, in which are found haemocytoblasts, myeloblasts, monocytoid $\vec{\sigma}$ haemoblasts, premyelocytes, and even some myelo- is cytes. In some rare cases, the percentage of premyelo- $\omega$ cytes among the medullary elements may be as high $\omega$ as 40. In two cases (personal observations) the $\frac{\text { ? }}{2}$ premyelocytes made up $40 \%$ and $43 \%$ of the myelogram; their features were identical with those seen in typical premyelocytic leukaemia, and this diagnosis could not be eliminated by cytological examination. On the other hand, the histology of the marrow was polymorphous and did not include a premyelocytic sheet of homogeneous type, as in our other observations. We believe that there must be described as borderline cases of acute premyelocytic leukaemia.

The acute premyelocytic transformation of a $\stackrel{\mathbb{D}}{\circ}$ chronic myeloid leukaemia is an infrequent form of $\overrightarrow{\vec{F}}$ acute transformation (Bernard et al., 1959). In these cases the smear contains a large number of premylocytes, but these differ from those of acute leukaemia, showing a closer similarity to normal premyelocytes, with finer and much less numerous granulations, always permitting examination of the nucleus. The histological data do not allow differentiation of the two types of cell, but in the case of transformation of chronic myeloid leukaemia, the features are more polymorphous. The cytology and the context of a case make differentiation easy.

\section{REFERENCES}

Bernard, J., Boirin, M., Weil, M., Levy, J. P., Seligmann, M., N and Najean, Y. (1962). Franc. Hémat., 2, 195.

Mathé, G., Boulay, J., Céoara, B., and Chomé, J. (1959). Schweiz. N med. Wschr., 89, 604.

Seligmann, M., and Kvicala, R. (1959). Rev. franc. Etud. clin. biol., 4, 1024. 
We wish to thank Sister Stewart, Dr. Lowry, and Dr. Neely for their cooperation and help in the collection of specimens and examinaton of case histories, and Dr. S. Nelson for the animal inoculations.

\section{REFERENCES}

Butt, W. R., Crooke, A. C., and Cunningham, F. J. (1961). Biochem. J., 81, 596.

Ling, N. R. (1960). Ibid. J., 77, 12P.

Wide, L., and Gemzell, C. A. (1960). Acta endocr. (Kbh.), 35, 261.

ADDENDUM

Since this paper was submitted for publication it is learned that Organon Laboratories have now reduced the sensitivity of their pregnancy test. A further series of tests have been carried out using this modified Pregnosticon. One false positive result was obtained from 115 non-pregnancy urines, and one false negative result from 78 pregnancy urines. These results indicate that Pregnosticon is now a satisfactory test for pregnancy diagnosis.

\section{CORRECTION}

The title of the paper by Jean Bernard, J. Lasneret, J. Chome, J. P. Levy, and M. Boiron (J. clin. Path., 16, 319) should read: 'A cytological and histological study of acute promyelocytic leukaemia'. Throughout, the nomenclature 'promyelocyte' should be used instead of 'premyelocyte'.

\section{Standardization of haemoglobin solutions by iron determination}

\author{
E. C. MASON and A. ADARRAGA-ELIZARAN From \\ the Red Cross Blood Transfusion Service, \\ Brisbane, Australia
}

Earlier evaluations of haemoglobin standards in this laboratory utilized a modification of the direct titanium sulphate microtitration of residual $\mathrm{Fe}$ in wet- or dry-ashed haemoglobin (McFarlane, 1932; Ramsay, 1944; O'Hagan 1957). In the spectrophotometric determination of a coloured complex formed by interaction of haemoglobin $\mathrm{Fe}$ with a sensitive reagent $\mathrm{Fe}$ is split from haemoglobin by wet-way oxidative procedures terminating in either partial destruction of the protein, requiring a subsequent filtration step (Wong, 1928; Sunderman, MacFate, MacFadyen, Stevenson, and Copeland, 1953; Dickenman, Crafts, and Zak, 1954), or in complete destruction of the protein followed by evaporation of residual volatile acids (Williams and Zak, 1957). Preliminary trials of the first alternative were not completely satisfactory in our hands, possibly because of partial irreversible absorption of $\mathrm{Fe}$ by the precipitated protein. On investigation of the second, certain modifications were introduced, including the elimination of the final evaporative step.

\section{MATERIALS AND METHODS}

REAGENTS All are made up in iron-free distilled water.

1 Buffered 2,2'-dipyridyl solution One gram of 2,2'dipyridyl is dissolved with warming in about $700 \mathrm{ml}$. water, and to this is added $300 \mathrm{~g}$. anhydrous sodium acetate (A.R.). When solution is complete, the whole is transferred to a one-litre volumetric flask and made up to the mark. This solution is stored in a dark glass bottle.

2 Mineral acids The concentrated acids used, $\mathrm{H}_{2} \mathrm{SO}_{4}$ (S.G. 1.83), $\mathrm{HNO}_{3}$, (S.G. 1.42) and $\mathrm{HClO}_{4}(72 \%$ ), are each of A.R. quality.

3 Ascorbic acid One gram is dissolved in $100 \mathrm{ml}$. water for each standardization. The solution is stored in a refrigerator when not in use but is discarded after 24 hours.

4 Standard iron stock solution This contains $10 \mathrm{mg}$. Fe per ml.; $86 \cdot 6 \mathrm{~g}$. $\left(\mathrm{Fe}_{2}\left(\mathrm{SO}_{4}\right)_{2} \cdot\left(\mathrm{NH}_{4}\right)_{2} \mathrm{SO}_{4} \cdot 24 \mathrm{H}_{2} \mathrm{O}\right.$ (A.R.) is dissolved in $400 \mathrm{ml}$. water, $200 \mathrm{ml} .10 \% \mathrm{H}_{2} \mathrm{SO}_{4}$ is added, and the solution is transferred to a one-litre volumetric flask and diluted to the mark. The iron content is accurately established by a standard oxidimetric procedure (Vogel, 1951).

5 Standard iron working solution Accurate 1/100 dilution of stock solution $=100 \mu \mathrm{g} . / \mathrm{ml}$.

APPARATUs All glassware must be free of iron. This is accomplished by cleaning with chromic acid, rinsing 